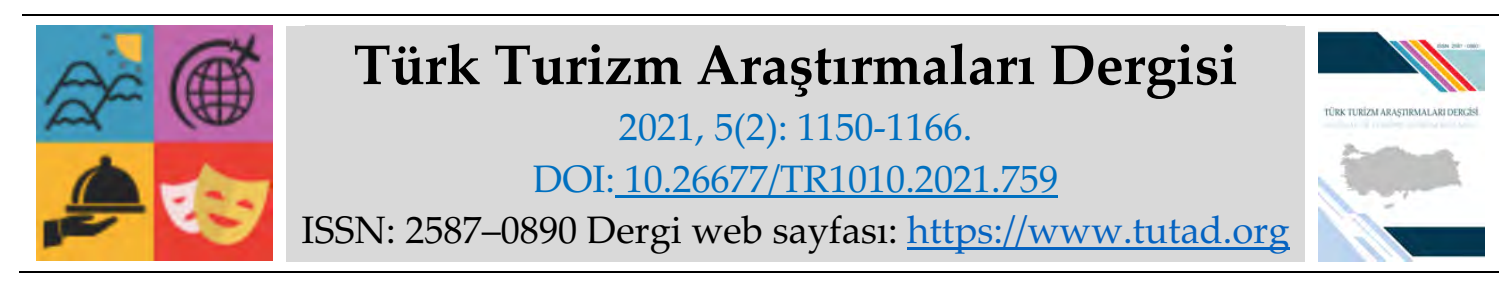

ARASTTIRMA MAKALESI

\title{
Beş Yıldızlı Otel İşletmelerinde Yetenek Yönetimi Uygulamalarının İş Tatmini Üzerindeki Etkisi: Belek Örneği
}

Dr. Öğr. Üyesi Eda ÖZGÜL KATLAV, Nevşehir Hacı Bektaş Veli Üniversitesi, Turizm Fakültesi, Nevşehir, e-posa: edaozgul@nevsehir.edu.tr ORCID: https://orcid.org/0000-0002-4168-909X

Dr. Emre AYKAÇ, Nevşehir Hacı Bektaş Veli Üniversitesi, Sosyal Bilimler Enstitüsü, Nevşehir, eposta: emreaykac1@hotmail.com ORCID: https://orcid.org/0000-0003-1700-0122

Öz

Otel işletmelerinde önemli bir rekabet unsuru olan insan kaynağı hizmet kalitesini arttırmak ve rekabet avantajı elde edebilmek için yetenekleri doğrultusunda yönetilmelidir. Yetenekli çalışanların işletmede tutulmasında ise çalışanların iş tatmini düzeyinin yüksek olması oldukça önemli olmaktadır. Bu nedenle çalışmanın amacı; otel işletmelerinde yetenek yönetiminin iş tatmini üzerindeki etkisini ortaya koymaktır. Araştırmada anket tekniği ile veriler toplanmış ve uygun istatistiki program aracilığıla frekans, yüzde, ortalama, korelasyon ve regresyon analizleri yapılmıştır. Belek'te faaliyet gösteren beş yıldızlı otel işletmelerinde çalışan toplam 412 işgörene anket uygulanmıştır. Analiz sonucunda işgörenlerin yetenek yönetimi boyutları (yönetim desteği, kariyer başarısı, işletmede sorumluluk almaktan duyulan gurur, işletmenin sosyal sorumluluğu, hijyen faktörler, işletmeden duyulan memnuniyet, işten ayrılma isteği ve performans yönetimi uygulamaları) ile iş tatminleri arasında anlamlı pozitif yönde etki olduğu tespit edilmiştir.

Anahtar Kelimeler: Yetenek Yönetimi, İş Tatmini, Turizm, Belek.

Makale Gönderme Tarihi: 07.03.2021

Makale Kabul Tarihi: 04.06.2021

\footnotetext{
Önerilen Atıf:

Özgül Katlav, E. ve Aykaç, E. (2021). Beş Yıldızlı Otel İşletmelerinde Yetenek Yönetimi Uygulamalarının İş Tatmini Üzerindeki Etkisi: Belek Örneği, Türk Turizm Araştırmaları Dergisi, 5(2): 1150-1166.

(C) 2021 Türk Turizm Araştırmaları Dergisi.
} 


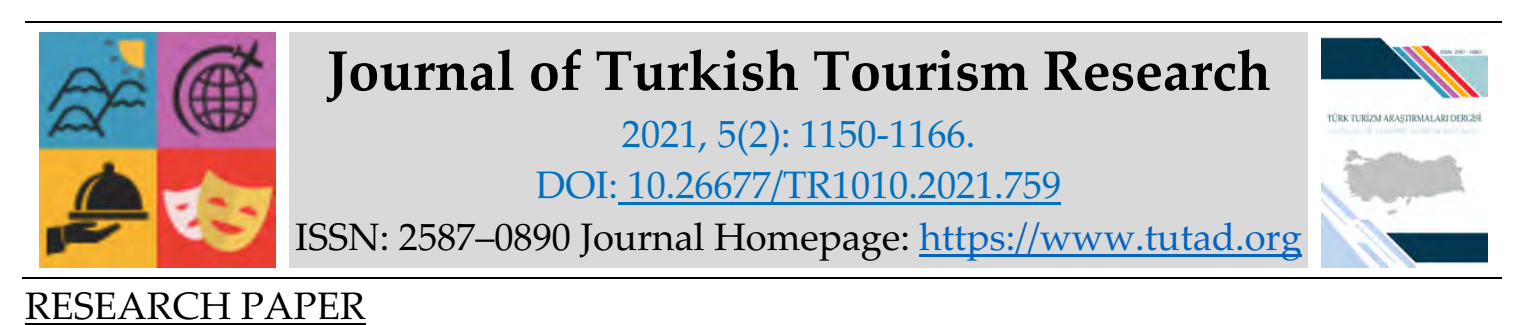

RESEARCH PAPER

\title{
The Effect of Talent Management Applications on Job Satisfaction in Five Star Hotels: Belek Case Study
}

Assistant Prof. Dr. Eda ÖZGÜL KATLAV, Nevşehir Hacı Bektaş Veli University, Faculty of Tourism, Nevşehir, e-mail: edaozgul@nevsehir.edu.tr ORCID: https://orcid.org/0000-0002-4168-909X

Dr. Emre AYKAÇ, Nevşehir Hacı Bektaş Veli University, Social Sciences Institute, Nevşehir, email: emreaykac1@hotmail.com

ORCID: https://orcid.org/0000-0003-1700-0122

\begin{abstract}
Human resources, which is an important competitive factor in hotel businesses, should be managed in line with the abilities of the staff in order to increase service quality and gain a competitive advantage. It is very important in terms of keeping talented staff in a hotel that the job satisfaction level of the staff is kept high. Therefore, the aim of the study is to reveal the effect of talent management on job satisfaction in hotel businesses. In the study, data were collected with the questionnaire technique and frequency, percentage, mean, correlation and regression analysis were performed by means of an appropriate statistical program. A questionnaire was applied to a total of 412 employees working in five-star hotel enterprises operating in Belek. As a result of the analysis, a significant positive effect was found between the talent management dimensions (management support, career success, pride in taking responsibility in the business, socially responsible employer, hygiene factors, satisfaction with the business, intention to leave and performance management practices) of the employees and their job satisfaction.
\end{abstract}

Keywords: Talent Management, Job Satisfaction, Tourism, Belek.

Received: 07.03.2021

Accepted: 04.06.2021

Suggested Citation:

Özgül Katlav, E. and Aykaç, E. (2021). The Effect of Talent Management Applications on Job Satisfaction in Five Star Hotels: Belek Case Study, Journal of Turkish Tourism Research, 5(2): 11501166.

(C) 2021 Türk Turizm Araştırmaları Dergisi. 


\section{Gíriş}

21. yüzyılda dünyada gayrisafi hasılanın önemli bir bölümünü oluşturan ve en hızlı gelişen sektörlerin başında turizm sektörü gelmektedir. Ulaşım ve iletişim teknolojisindeki gelişmelerle birlikte maliyetlerin azalmış ve insanları daha önce görmedikleri yerlerden haberdar olmuşlardır. Bununla birlikte bireylerin harcanabilir gelirlerinden turizm için ayrılan payın artması turizme katılan insan sayısının artmasını sağlamıştır (Albeni ve Ongun, 2005; Akıncı ve Yüzbaşığlu, 2015; Gürbüz ve Uçar, 2017). Daha fazla seyahat eden turistler gittikleri ülkelerden ve orada yer alan turizm işletmelerinden daha kaliteli hizmet almak istemektedir. Bu durum bir destinasyonu ya da işletmeyi tercih edecek turistler için önemli karar verme kriterlerinden biri olmaktadır. Konaklama işletmeleri müşteriler tarafından tercih edilmek ve rakiplerine karşı rekabet üstünlüğü sağlayabilmek için rekabet avantajı ve sürdürülebilirlik bağlamında tedbirler almak zorunda kalmıştır. Başka bir deyişle konaklama işletmeleri için varlıklarını sürdürebilmek daha fazla rekabetçi olmalarıyla eşdeğer hale gelmiştir (Akar ve Balcı, 2016: 956). İşletmelerin rekabet edebilmeleri ve rekabette üstünlük sağlayabilmeleri için çevresindeki değişimlere daha esnek tepkide bulunma becerisine sahip olması büyük önem taşımaktadır (Erol, 2010: 87). Bu anlamda yeteneklerin yönetimi, işletmelerin artan rekabet gücü ile ilgili taleplerini karşılamalarını sağlayan bir yöntem olarak kabul edilmektedir (Vnoučkova, 2016: 701).

Hizmet endüstrisi içinde yer alan konaklama işletmelerinin emek yoğun bir yapısı bulunmaktadır. Konaklama işletmeleri için yetenekli çalışanları işe almak ve işletmede uzun süre çalışmasını sağlamak önemlidir. Çünkü konaklama işletmelerinde işgören; kalitenin, başarının, karlılığın ve verimliliğin en önemli belirleyicisidir. Hizmet kalitesinin belirli standartta verilmesi, nitelikli ve deneyimli işgörenlerle mümkün olmaktadır (Tuna, 2007). Ancak konaklama işletmelerinin yetenekli personel bulması ve işletmede devamlılığını sağlaması zordur. 2019 yılında Manpower Group tarafından Türkiye'de yapılan Yetenek Açığı Araştırması'na göre meslek grupları içinde en zor bulunan yetenekler arasında konaklama yani restoran ve otel çalışanı bulunmaktadır (Manpower Türkiye, Yetenek Açı̆̆ı Raporu, 2019). Konaklama işletmelerindeki uzun çalışma saatleri, düşük ücretler, kariyer fırsatlarının olmaması, işletmelerin sezonluk hizmet vermesi, turizm sektörünün belirsiz yapısı gibi nedenler ve bu nedenlerin işgücü devir hızını arttırması yetenekli çalışanların işletmede kalmasını olumsuz etkilemektedir. Bu durumda yetenek yönetimi, turizm sektöründe yaşanan bu olumsuzlukların aşılmasında ilgi çekici fırsatlar sunmaktadır (Çevik, 2014).

Etkin bir yetenek yönetiminin ise, konaklama işletmelerinin yeteneklerini nasıl çektiklerine, geliştirdiklerine, muhafaza ettiklerine, yönettiklerine, ödüllendirdiklerine ve tatmin ettiklerine bağlı olduğu ifade edilmektedir (Ahmed, 2016: 30). İş tatmini işletmelerin etkinliği ve verimliliği konusunda ana faktörlerin başında gelmektedir (Aypar vd., 2018: 116). Ancak iş tatmininin sağlanması amacıyla yeteneklerin yönetilmesi yöneticilerin karşılaştı̆̆ı en karmaşık işlerin başında gelmektedir (Aziri, 2011: 77). Bu nedenle günümüzde yaşanan yoğun rekabet ortamında, konaklama işletmelerinin ayakta kalabilmeleri için sahip oldukları finansal kaynakların ötesinde, bünyelerinde faaliyet gösteren insan kaynağının yeteneklerini iyi yönetmeleri gerekmektedir (Aksoy ve Sökmen, 2018: 200). Bu çalışmada otel işletmelerindeki işgörenlerin yeteneklerinin yönetilmesinin iş tatminlerini nasıl etkilediği ortaya konmuştur.

\section{KURAMSAL ÇERÇEVE YETENEK YÖNETIMII}

Dünya genelinde önemli oranda istihdam, ödemeler dengesi ve bölgesel kalkınma gibi sayısız ekonomik etkileri olan (Alpaslan ve Tutar, 2018: 48) turizm pazarının büyümesi, turizm sektörü 
kapsamına giren birimlerden biri olan otel işletmelerini giderek şiddetli bir rekabete zorlamıştır (Ratih ve Yunus, 2016: 1). Dünyada büyük bir ivme kazanmış olan turizm endüstrisinin sağlamış olduğu yararlardan daha yüksek oranda yararlanmak isteyen ülkeler arasındaki rekabet yükselmektedir. Bu bağlamda mevcut rekabet koşullarında otel işletmelerinin sağlayacağ başarının da insan kaynaklarının kalitesiyle ortaya çıkacağı düşünülmektedir (Erdem, 2003). İnsan kaynakları denilince de günümüzde nispeten yeni bir anlayış olan yetenek ve yetenek yönetimi kavramları akla gelmektedir (Waheed ve Zaim, 2015: 1206; King, 2015: 277).

1926 yılında James O. McKinsey tarafından Chicago da kurulan Mckinsey uluslararası yönetim danışmanlık firması 1997 yılında yaptığı "yetenek savaşları" araştırmasıyla 2000 yılı başlarında yetenek yönetimi kavramı üzerinde konuşulmaya başlanmıştır. Araştırmanın sonucunda başarıya sahip işletmelerin tutarlı ve sürdürülebilir yetenek yönetimi uygulamalarına sahip oldukları tespit edilmiştir (Aytaç, 2014: 2). Bu gelişmelerden sonra geleneksel insan kaynakları yaklaşımının bakış açısını değişmiş (Collings ve Mellahi, 2009: 305) ve yetenek yönetimi, insan kaynakları departmanının başarısını belirleyen bir yaklaşım haline gelmiştir (Bat ve Yalçın, 2015: 95).

Yetenek; Türkçe sözlükte "kabiliyet, istidat" anlamlarına gelmektedir (www.tdk.gov.tr, 2020). Akar (2015: 17)'a göre yetenek; bir kişinin birden fazla konu veya alana sahip olduğu içsel ve üst düzey kabiliyetidir. Bu kabiliyetler işletmeler için stratejik öneme sahiptir. Bu kabiliyetlerin yokluğu işletme için gerçek bir kriz durumu oluşturabilmektedir (Baqutayan, 2014: 2290). Bu kapsamda konaklama işletmeleri açısından yetenek, işletmelerin teknik ve stratejik açıdan avantajlar sağlayabilecek ve bunları insanlara uyarlayabilecek yeteneklerin bütünleştirilmesini ve sürdürülebilmesini sağlayacak bir rekabet üstünlüğü tasarımı şeklinde ele alınmaktadır (Ağraş ve Kılınç, 2014: 3). Yetenek kavramına bağlı olarak gelişen yetenek yönetimi ise çeşitli şekillerde tanımlanmış ve uygulanmıştır (Annakis vd., 2014: 164). Bu çalışmada kavram insan kaynakları perspektifinden ele alınmıştır.

Yetenek yönetimi, bir işletmenin doğru zaman ve işlerde yüksek derecede üretken bireylere sahip olmayı sağlama süreci olarak ifade edilirken (Vnoučkova, 2016: 702), organizasyonların insan kaynakları departmanının bir alt sistemi ve yönetimsel açıdan da yetenek gelişim problemleri ile baş edebilmek için örgütler tarafından oluşturulan planları içermektedir (Altunoğlu vd., 2015: 49). Başka bir deyişle yetenek yönetimi, konaklama işletmelerinin uzun vadeli stratejiler doğrultusunda yüksek performans gösteren kişileri işe alması, geliştirmesi, yerleştirmesi, çalışanları elde tutması gibi çalışmaları bütünleştirme süreci olarak tanımlanabilir (Akar ve Balcı, 2016: 957). Yetenek yönetimi; gelecek dönemlerdeki gereksinimleri karşılamak ve stratejik hedeflere ulaşmak üzere yeteneklerin işletmeye çekilmesi, geliştirilmesi ve elde tutulması için işletme tarafından planlanan süreçleri ifade etmektedir (Altıntaş, 2018: 32; Annakis vd., 2014: 165). Yetenek yönetimi, iş performansına katkıda bulunma potansiyeline sahip, yüksek performanslı bir bireyler havuzu şeklinde tanımlanabilir (King, 2015: 275). Tanımlardan anlaşılacağı üzere, yetenek yönetimini uygulayan işletmeler aşağıdaki stratejileri izlemekte veya işletmeyle bütünleştirmektedir (Kaur, 2013: 62):

- İşe Alma; işletmeye doğru kişilerin çekilmesini ve istihdam edilmesini sağlamak,

- Elde Tutma; çalışanları ödüllendiren ve destekleyen geliştirme uygulamaları,

- Mesleki Gelişim; sürekli resmi öğrenim ve gelişimin sağlanması,

- Performans Yönetimi; geri besleme de dâhil olmak üzere performansı besleyen ve destekleyen özel süreçler,

- İşgücü Planlamasl; eski işgücü ve mevcut/gelecek beceri eksiklikleri dâhil olmak üzere iş ve genel değişiklikler için planlama,

- Kültür; pozitif, ilerici ve yüksek performanslı çalışma şeklinin geliştirilmesidir. 
Bir işletmedeki çalışanların yeteneklerinin toplamı, büyük ölçüde işletmenin temel yeteneklerini içermektedir. İşletmenin sahip olduğu yetenek, rakiplerin kıyaslama ve tekrarlama yapmasını zorlaştırabilmektedir (Iyria, 2013: 287). Bu yaklaşımın değerini anlayan işletmeler, yetenek yönetimi konusuna yoğunlaşarak uzun vadede karlılık ve başarılarını artırmayı hedeflemektedirler (Bat ve Yalçın, 2015: 95). Bu nedenle günümüz yöneticilerinin çoğu, hedeflenen örgütsel amaçlara erişebilmek üzere örgütün bütün kaynaklarını koordine ederek ortak emek, beklenti ve arzu oluşturma çabasındadırlar. Bu süreçte çalışanlar, hedeflere ulaşmada işletmenin kaynakları arasında kilit bir role sahiptirler (Fidan ve Küçükali, 2014: 319). İşte bu derece önemli olan çalışanların, işlerinden tatmin olmalarını sağlamanın ve çalışanların örgüte olan bağlılıklarının arttırılmasında (Eroğlu, 2002: 166) yeteneklerinin doğru bir biçimde yönetilmesi büyük bir önem arz etmektedir.

\section{IŞ TATMINi}

İnsanlar yaşamlarının ciddi bir kısmını mesleklerini icra ettikleri işletmelerde geçirmektedirler. İşletmelerde geçirilen bu süre zarfında, kişilerin yürütmüş oldukları görevler birtakım değerlendirmeler yapmalarına neden olmaktadır (Ak, 2017: 35). Yapılan değerlendirmelerin sonuçlarından biri olan iş tatmini, öyle ki çalışanların ekonomik ve psikolojik durumlarını önemli ölçüde etkileyen bir unsurdur (Can vd., 2009: 229; Yaya, 2016: 98).

Kavram olarak tatmin; ulaşılan neticenin doyumu ne kadar tamamladığı ile ilgili bir durum olarak tanımlanmaktadır (Demirdelen ve Ulama, 2013: 68; Başbuğa vd., 2018: 18). İş tatmini ise, kişinin işe veya göreve yönelik olumlu duygusal tepkimesi (Demir vd., 2008: 140; Islam vd., 2012: 153), çalışanların sahip olduğu özel bir davranış durumu (Kitapçı ve Sezen, 2002: 220) şeklinde tanımlanmaktadır. Bir diğer tanımlamayla çalışanların iş tecrübesi sonucu elde edilen olumlu ruh halidir (Karataş ve Güleş, 2010: 75; Amalia, 2018: 12). Bu ruh hali çalışanların geçmiş çalışma hayatı, beklentisi ve elde edilen seçeneklere göre şekillenen bir durumdur (Şahin, 2013: 13). Dolayısıyla iş tatminine yönelik tanımlardan görülmekte ki iş tatmini, genel manada çalışanların işlerindeki mutluluk düzeylerine yönelik bir durum analizidir (Bozkurt ve Bozkurt, 2008: 2; Spector, 1997: 2).

İş tatminine yönelik yapılan çalışmalar, kişilerin iş tatmin düzeyinde bireysel ve örgütsel unsurların etkisini ortaya koymuştur (Karataş ve Güleş, 2010: 76; Aypar vd., 2018: 117). Bireysel unsurlar; bireyin kişiliği, duyguları, düşünceleri, istekleri ve mevcut ihtiyaçları ile bunların etki seviyeleriyle bağlantısıdır (Kök, 2006: 293). Ücret, çalışma koşulları, yükselme fırsatları, işin doğası ve niteliği, iletişim ve işletme politikaları ise örgütsel unsurlardır (Yeşilyurt ve Koçak, 2014: 305). Çalışanların örgütsel faktörlere ilişkin olumlu tutumları iş tatminini doğurmaktadır. Aksi durumda çalışanların çalışma şartları, yükselme fırsatları, adil olmayan ücret vb. nedenlerle işletmeye, işverene veya iş arkadaşlarına karşı olumsuz bir tutum sergileyecekleri ve bunun da tatminsizliği doğurabileceği ifade edilmektedir (Akinbobola, 2011: 92; Başclllar ve Taşci, 2018: 334).

İş tatmininde etkili olan bireysel ve örgütsel unsurların yine aynı bağlamda bir dizi önemli sonuçlarının da olduğu görülmüştür. İlk olarak çalışma koşulları ile bağlantılı sorumluluk, görevin çeşitliliği ve iletişimdir. Ek olarak, devamsızlık, örgütsel etkisizlik ve verimlilik karşıtı davranışlar şeklinde sonuçlar tespit edilmiştir. Bu sonuçlar ve bunların çıkardığı problemler doğrudan işletmeye yöneliktir (Yüksel, 2005: 295-296). Bu bakımdan işten ayrılma niyetinin düşük olması iş tatmininin yüksek olduğunun göstergesidir (Çekmecelioğlu, 2006: 157). İş tatminsizliği ise çalışanların beklentilerinin gerçekleşmediği zamanlarda ortaya çıkmaktadır (Aksu, 2012: 61). İş tatminine önem veren konaklama işletmeleri, çalışanların ihtiyaçlarını ve beklentilerini karşılayan, personel istihdamında zorlanmayan, insanların devamlı olarak 
çalışmak istedikleri işletmelerdir (Bağcı ve Demir, 2017: 344). Nitekim iş tatminsizliği yüksek konaklama işletmeleri ise personel istihdam zorluğu, yüksek iş gören devir hızına sahip ve sonuç olarak verimliliği düşük işletmelerdir. Tüm bu sonuçlar dahilinde iş tatmininin organizasyonlar açısından ciddi önem arz ettiği görülmektedir (Üngüren vd., 2010: 2925).

\section{IŞ TATMINII ve YETENEK YÖNETIMII İLIŞKISII}

Yetenek yönetim ve iş tatmini üzerine yapılan araştırmalarda (Serim Bahadınlı, 2013; Hamidi, Saberi ve Safari, 2014; Tash, Ali ve Ahmadzadeh, 2016; Kamal ve Lukman, 2017; Hafez vd., 2017; Yalçın, 2017; İpçioğlu, 2017; Tarakcı ve Öneren, 2018; Lei, Basit ve Hassan, 2018; Dixit ve Arrawatia, 2018; Altındağ, Çırak ve Acar, 2018; Akgemci, Canbolat ve Kalfaoğlu, 2020) organizasyonlarda yetenek yönetimi uygulamalarının olması çalışanların iş tatmini algısını etkilediğini göstermektedir. Ayrıca iş tatmini yetenek yönetimi uygulamalarının başarılı olup olmamasında önemli bir kriter olmaktadır (Hamidi, Saberi ve Safari, 2014). Bu çalışmalar incelendiğinde yetenek yönetiminin sadece örgütsel sonuçlarla ilişkili olmadığı, aynı zamanda çalışanların tutumlarını biçimlendirmede önemli bir rol oynadığı ortaya çıkmıştır. Özellikle yetenek yönetimi ile ortaya çıkan kariyer gelişim fırsatlarının çalışanların motivasyonlarını artırdığı belirtilmiştir (Dixit vd., 2018: 433). Yetenek yönetimi stratejileri, çalışanların işlerinden memnun hissetmelerini sağlayan şeylere hitap etmelidir. Örneğin, mesleki eğitim ve gelişim, çalışanların becerilerinin kullanılmasını talep eden ve büyük bir grup çalışanla bağlantılı tutkularını ve duygularını arttıran çalışma ödevleri. Bunlar, çalışanlarının kuruluşlarına kendilerini motive ve bağlı hissetmek için ihtiyaç duydukları şeylerdir (Hafez vd., 2017).

Yetenek yönetimi ve iş tatmini arasındaki ilişki incelenmiş ve değişkenler arasında pozitif yönlü bir ilişki olduğu tespit edilmiştir (Serim Bahadınlı, 2013; Hamidi, Saberi ve Safari, 2014; Tash, Ali ve Ahmadzadeh, 2016; Kamal ve Lukman, 2017; Hafez vd., 2017; Yalçın, 2017; İpçioğlu, 2017; Tarakcı ve Öneren, 2018; Lei, Basit ve Hassan, 2018; Dixit ve Arrawatia, 2018; Altındağ, Çırak ve Acar, 2018; Akgemci, Canbolat ve Kalfaoğlu, 2020). Bu nedenle çalışmada yetenek yönetiminin boyutları ve iş tatmini arasında bir ilişki olduğu varsayılmaktadır. Araştırmada, otel çalışanların da yetenek yönetimi ile iş tatmini ilişkisi incelenmiş ve araştırma hipotezleri şöyle geliştirilmiştir:

$\mathrm{H}_{1 a}$ : İşletmenin sosyal sorumluluğu boyutunun iş tatmini üzerinde anlamlı bir etkisi vardır.

$\mathrm{H}_{1 b}$ : Yönetim desteği boyutunun iş tatmini üzerinde anlamlı bir etkisi vardır.

Hı: İşletmede sorumluluk almaktan duyulan gurur boyutunun iş tatmini üzerinde anlamlı bir etkisi vardır.

Hıd: Performans yönetimi uygulamaları boyutunun iş tatmini üzerinde anlamlı bir etkisi vardır.

$\mathrm{H}_{1}$ : Hijyen faktörleri boyutunun iş tatmini üzerinde anlamlı bir etkisi vardır.

Hıf: İşletmeden duyulan memnuniyet boyutunun iş tatmini üzerinde anlamlı bir etkisi vardır.

$\mathrm{H}_{1 \mathrm{~g}}$ : Kişisel başarı boyutunun iş tatmini üzerinde anlamlı bir etkisi vardır.

$\mathrm{H}_{1 \dddot{g}:}$ İşten ayrılma isteği boyutunun iş tatmini üzerinde anlamlı bir etkisi vardır.

\section{YÖNTEM}

\section{ÖRNEKLEM}

Antalya ilinde faaliyet gösteren beş yıldızlı otel işletmelerinde çalışan işgörenler araştırmanın evrenini oluşturmaktadır. Çalışmada işletmeye personel seçiminde ve daha sonraki çalışma 
sürecinde daha profesyonel olmaları sebebiyle beş yıldızlı oteller seçilmiştir. Bu nedenle bir, iki, üç ve dört yıldızlı otel işletmeleri araştırma dışında bırakılmıştır. Zaman ve maliyet kısıtları nedeniyle çalışmada örnekleme yöntemlerinden yararlanılmıştır. Araştırmada tesadüfî olmayan örnekleme yöntemlerinden yargısal örnekleme yöntemine başvurulmuştur. Bu örneklem yönteminde örneğe kimin seçileceğinin kararı araştırmacının kendisine bırakılmakta ya da uzman görüşü alınmaktadır. Yargısal örnekleme yönteminde, seçilen örneğin araştırmanın amacına uygun olduğu ve istenilen bilgiyi doğru bir şekilde sağlayacağı varsayılmaktadır (Nakip 2003; Gürbüz, Şahin, 2014).

Antalya Bölgesi'nde beş yıldızlı oteller genellikle Belek, Kundu, Alanya, Side ve Manavgat Bölgesinde yer almaktadır. Antalya İl Kültür ve Turizmi Müdürlüğü verilerine göre 2019 yılında beş yıldızlı otel ve tatil köyü toplam tesis sayısı $407^{\prime}$ dir. Zaman ve maliyet kısıtı sebebiyle bu çalışmanın örneklemi Antalya Belek'te hizmet veren beş yıldızlı otel işletmesi çalışanlarından oluşturmaktadır. Bu bölgede bulunan otellerde mevsimlik çalışanların sayısının da değişmesi nedeniyle otel işletmelerinde çalışan sayılarını net bir şekilde belirlemek oldukça güç olmaktadır. Otel çalışanlarına yönelik yapılan araştırmalar incelendiğinde (Katlav ve Perçin, 2019; Özkoç ve Katlav, 2015; Özkoç ve Çalışkan, 2015) örneklem hesaplama yönteminin yatak kapasitesine göre yapıldığ görülmektedir.

Antalya İl Kültür ve Turizm Müdürlüğü'nün 2019 yılı verilerine göre Belek ilinin bağlı olduğu Serik ilçesinde 62.000 yatak kapasiteli 57 adet beş yıldızlı otel işletmesi ve 6 adet tatil köyü bulunmaktadır. Türkiye'de beş yıldızlı işletmelerde yatak başına 0.59 işgören düşmektedir (Ağaoğlu, 1992). Bu rakamlardan hareketle Serik bölgesinde beş yıldızlı işletmeler için 36.580 işgören olduğu tahmin edilmektedir. Evreni temsil edebilecek örneklem hacmi \%95 güven düzeyinde 384 çalışan olarak hesaplanmıştır. Kabul edilebilir örneklem büyüklüğüne ulaşabilmek için 500 anket formu, anketi yapmak için onay veren otel işletmelerinde uygulanmış ve sonuçta geçerli 412 anket değerlendirmeye alınmıştır. Örneklem büyüklüğünün yaklaşık $\% 82$ 'sinden geri bildirim alınmıştır.

\section{VERI TOPLAMA ARACI}

Bu çalışmada anket tekniğinden yararlanılmıştır. Anket formunda yetenek yönetimi ve iş tatmini değişkenleri ile katılımcılara ilişkin demografik sorular yer almaktadır. Yetenek yönetimi algısını ölçmek için Tymon JR vd., (2009) ve Wieselsberger (2004) tarafından geliştirilen ve Tutar, Altınöz ve Çöp (2011) tarafından geçerlilik ve güvenirlik çalışmaları yapılan ölçekten yararlanılmıştır. Yetenek yönetimi ölçeği; işletmenin sosyal sorumluluğu, yönetim desteği, işletmede sorumluluk almaktan duyulan gurur, performans yönetimi, hijyen faktörleri, işletmeden duyulan memnuniyet, kişisel başarı ve işten ayrılma isteği olmak üzere sekiz boyuttan oluşmaktadır. İş tatmini değişkenini ölçmek için Smith, Kendal ve Hulin (1987) tarafından geliştirilen ve Ergin (1997) tarafından Türkçe'ye geçerlilik ve güvenirlik çalışması yapılan ölçüm aracı kullanılmıştır. Anket formunun ikinci bölümünde araştırmaya katılan kişilerle ilgili demografik sorular (cinsiyet, medeni durum, gelir, yaş, çalışılan bölüm ve çalışma süresi) yer almıştır.

\section{ARAŞTIRMANIN BULGULARI}

Araştırma kapsamında elde edilen veriler tanımlayıcı analizler (frekans, yüzde, ortalama, standart sapma), korelasyon, regresyon analizleri ile analiz edilmiştir. Katılımcıların demografik özelliklerine ilişkin bulgular Tablo 1'de yer almaktadır. 
Tablo 1'de ki dağglıma göre araştırma kapsamındaki 412 işgörenin \%28,6'sı kadın olup, \%71,4'ü ise erkektir. Medeni durumlarına yönelik olarak \%14,1'i evli, \%85,9'u bekârdır. Çalışanların yaşlarına göre dağılımı incelendiğinde, $\% 65,5^{\prime}$ inin 25 ve altı yaş aralığında, \%27,4'ü 26-35 yaş aralığında, \%4,9'unun 36-45 yaş aralığında, \%1,0'sının 46-55 yaş aralığında ve \%1,2'sinin 56 ve üzeri yaş aralığında olduğu tespit edilmiştir. Araştırmaya dâhil edilen çalışanların büyük bir bölümü \%52,7'sinin lise, \%20,1'inin lisans, \%17,2'si önlisans, $\% 8,3^{\prime}$ ü ilkokul eğitim derecesine sahip olup, \%1,7'si ise lisansüstü eğitim derecesine sahiptir. İşletmedeki statüleri itibariyle $\% 26,7^{\prime}$ si stajyer, \%40,8'in geçici/sezonluk çalışan ve \%32,5'in kadrolu çalışan olduğu görülmektedir. İşgörenlerin çalıştıkları departmanlara yönelik veriler incelendiğinde; yiyecekiçecek $\% 39,8^{\prime}$ i, kat hizmetleri $\% 10,2^{\prime}$ si, mutfak $\% 11,7^{\prime}$ si, önbüro $\% 13,1^{\prime} i$, güvenlik $\% 11,9^{\prime}$ u ve golf departmanı da \%13,3'lük kısmını temsil ettiği görülmektedir. Çalışanların aylık gelirleri incelendiğinde $500 \mathrm{TL}$ ve altı $\% 6,1^{\prime} \mathrm{i}, 501-1000 \mathrm{TL}$ arası \%34,7'sini, 1001-1500 TL arası \%41,3'ünü, 1501-2000 TL arası \%13,1'i, 2001 TL ve daha çok ise \%4,8'lik kısımla aylık gelir elde eden katılımcı belirlenmiş̧ir. Son olarak ilgili tabloda bulunan ve örneklem grubunda yer alan işgörenlerin işletmedeki çalışma sürelerine göre dağılımı incelendiğinde, katılımcıların \%61,2'sinin işletmedeki çalışma süresinin 1 yılın altında, \%27,9'unun 2-5 yıl arasında ve \%10,9'u ise 6 yıl ve üzerinde olduğu görülmektedir.

Tablo 1. Araştırmaya Katılan Çalışanların Demografik Özelliklerine İlişkin Dağılımları

\begin{tabular}{|c|c|c|c|c|c|c|c|}
\hline Değişkenler & Gruplar & $\mathrm{f}$ & $\%$ & Değişkenler & Gruplar & $\mathrm{f}$ & $\%$ \\
\hline \multirow[t]{2}{*}{ Cinsiyet } & Kadın & 118 & 28,6 & \multirow{5}{*}{ Aylık Gelir } & 500 TL ve alt1 & 25 & 6,1 \\
\hline & Erkek & 294 & 71,4 & & $501-1000 \mathrm{TL}$ & 143 & 34,7 \\
\hline \multirow{2}{*}{$\begin{array}{l}\text { Medeni } \\
\text { Durum }\end{array}$} & Evli & 58 & 14,1 & & $1001-1500 \mathrm{TL}$ & 170 & 41,3 \\
\hline & Bekâr & 354 & 85,9 & & $1501-2000 \mathrm{TL}$ & 54 & 13,1 \\
\hline \multirow{4}{*}{ Yaş } & $26-35$ & 113 & 27,4 & & 2001 TL ve üstü & 20 & 4,8 \\
\hline & $36-45$ & 20 & 4,9 & \multirow{6}{*}{$\begin{array}{l}\text { Çalışılan } \\
\text { Bölüm }\end{array}$} & Yiyecek İçecek & 164 & 39,8 \\
\hline & $46-55$ & 4 & 1,0 & & Kat Hizmetleri & 42 & 10,2 \\
\hline & 56 ve üstü & 5 & 1,2 & & Mutfak & 48 & 11,7 \\
\hline \multirow{5}{*}{$\begin{array}{l}\text { Eğitim } \\
\text { Durumu }\end{array}$} & İlköğretim & 34 & 8,3 & & Önbüro & 54 & 13,1 \\
\hline & Lise & 217 & 52,7 & & Güvenlik & 49 & 11,9 \\
\hline & Ön Lisans & 71 & 17,2 & & Golf & 55 & 13,3 \\
\hline & Lisans & 83 & 20,1 & \multirow{5}{*}{$\begin{array}{l}\text { İşletme } \\
\text { Çalışma } \\
\text { Süresi }\end{array}$} & 1 yıl ve daha az & 252 & 61,2 \\
\hline & Lisansüstü & 7 & 1,7 & & $2-5$ y1l & 115 & 27,9 \\
\hline \multirow{3}{*}{$\begin{array}{l}\text { İşletmedeki } \\
\text { Statü }\end{array}$} & Stajyer & 110 & 26,7 & & \multirow[t]{3}{*}{6 ve üzeri } & \multirow[t]{3}{*}{45} & \multirow[t]{3}{*}{10,9} \\
\hline & Geçici/Sezonluk & 168 & 40,8 & & & & \\
\hline & Kadrolu & 134 & 32,5 & & & & \\
\hline
\end{tabular}

Araştırma değişkenlerine ilişkin analizler yapılmadan önce araştırmada kullanılan ölçekler geçerlilik ve güvenirlik açısından incelenmiştir. Tablo 2' de görüldüğü gibi her bir ölçeğe ve ölçekteki her bir boyuta ilişkin Güvenirlik katsayılarının ( $\alpha$ ), 0,70 ile 0,90 arasında olduğu görülmektedir. Bu değerlerin kabul edilebilir düzeyde olduğu ve ölçeklerin güvenilir olduğu söylenebilir (Gürbüz ve Şahin, 2014).

Araştırma hipotezlerini test etmek için yapılacak istatistiksek analiz öncesinde değişkenlerin normal dağılım gösterip göstermedikleri incelenmiştir. Normal dağılımı belirlemek için basıklık ve çarpıklık değerleri incelenmiştir. Basıklık değerleri 0.988/1.089 ve çarpıklık değerleri 
1.691/1.452 arasında olduğu için veriler normal dağılım göstermektedir (Shiel ve Cartwright, 2015: 28).

Tablo 2. Değişkenlere Ait Ortalama, Standart Sapma Değerleri

\begin{tabular}{|c|c|c|c|}
\hline Ölçekler & $\begin{array}{c}\text { Genel } \\
\text { Ortalama }\end{array}$ & $\begin{array}{c}\text { Standart } \\
\text { Sapma }\end{array}$ & $\begin{array}{c}\text { Güvenirlik } \\
\text { Katsayısı } \\
(\alpha)\end{array}$ \\
\hline İş Tatmini ${ }^{1}$ & 2,88 & 0,513 & ,728 \\
\hline Yetenek Yönetimi $^{2}$ & 3,02 & 0,746 & ,915 \\
\hline İşletmenin sosyal sorumluluğu ${ }^{2}$ & 3,31 & 0,967 & 889 \\
\hline Yönetim desteğ $\mathrm{i}^{2}$ & 3,11 & 1,087 & 879 \\
\hline İşletmede sorumluluk almaktan duyulan gurur ${ }^{2}$ & 3,16 & 1,071 & ,902 \\
\hline Performans yönetimi uygulamaları ${ }^{2}$ & 2,81 & 1,158 & 894 \\
\hline Hijyen faktörler ${ }^{2}$ & 3,10 & 1,010 & ,901 \\
\hline${\text { İşletmeden duyulan memnuniyet }{ }^{2}}^{2}$ & 3,11 & 1,182 & 897 \\
\hline Kariyer başarısı $^{2}$ & 2,61 & 1,112 & 887 \\
\hline İşletmeden ayrılma isteği $\mathrm{i}^{2}$ & 2,84 & 1,32 & 873 \\
\hline
\end{tabular}

Ölçek 1,2: 1=Kesinlikle katılmıyorum, 2=Katılmıyorum, 3= Ne katılıyorum ne katılmıyorum, 4=Katılıyorum, $5=$ Kesinlikle katiliyorum

Tablo 3'te katılımcıların yetenek yönetimi ve iş tatmini alt boyutlarına yönelik görüşleri "Korelasyon Analizi (Pearson Korelasyon Katsayısı)" ile ilişkisel açıdan değerlendirilmiştir.

Tablo 3. İş Tatmini ve Yetenek Yönetimi Algısı Arasındaki İlişkinin İncelenmesi (Korelasyon Analizi)

\begin{tabular}{|c|c|c|c|c|c|c|c|c|c|c|}
\hline Ölçekler & 1 & 2 & 3 & 4 & 5 & 6 & 7 & 8 & 9 & 10 \\
\hline 1. İş Tatmini & 1 & & & & & & & & & \\
\hline $\begin{array}{l}\text { 2.İşletmenin Sosyal } \\
\text { Sorumluluğu }\end{array}$ & ,462* & 1 & & & & & & & & \\
\hline 3.Yönetimin Desteği &, $462^{* *}$ & $623^{* *}$ & 1 & & & & & & & \\
\hline $\begin{array}{l}\text { 4. İsletmeden Alınan } \\
\text { Sorumluluk }\end{array}$ & ,482** &, $546^{* *}$ & ,729** & 1 & & & & & & \\
\hline $\begin{array}{l}\text { 5.Performans } \\
\text { Yönetimi } \\
\text { Uygulamaları }\end{array}$ & $483^{* *}$ & $486^{* *}$ & $679^{* * *}$ & ,580* & 1 & & & & & \\
\hline 6. Hijyen Faktörleri & , $444^{* *}$ &, $530^{* *}$ & $635^{* *+}$ & $608^{* *}$ &, $518^{* *}$ & 1 & & & & \\
\hline $\begin{array}{l}\text { 7. İşletmeden } \\
\text { Duyulan } \\
\text { Memnuniyet }\end{array}$ & $460^{* * *}$ & $497^{* *}$ &, $588^{* *}$ & $712^{* *}$ &, $587^{* *}$ &, $552^{* *}$ & 1 & & & \\
\hline 8. Kariyer Başarısı &, $419^{* *}$ &, $424^{* *}$ &, $524^{* *}$ &, $549^{* *}$ &, $592^{* *}$ & $436^{* *}$ & $609^{* *}$ & 1 & & \\
\hline $\begin{array}{l}\text { 9. İşletmeden } \\
\text { Ayrılma İsteği }\end{array}$ & ,033 & - & $-162^{* *}$ & $-{ }^{-}, 276^{* *}$ & $-1,164^{* *}$ & $-121^{*}$ & - & - $288^{* *}$ & 1 & \\
\hline $\begin{array}{l}\text { 10. Genel Yetenek } \\
\text { Yönetimi }\end{array}$ & ,605* & 740 & $860^{* *+}$ & $831^{* *}$ & $723^{* * *}$ & , $755^{* *}$ & ,772** & $728^{* *}$ & $\begin{array}{l}- \\
085 \\
\end{array}$ & 1 \\
\hline
\end{tabular}

${ }^{* *} \mathrm{p}<0,001 \quad{ }^{*} \mathrm{p}<0,05$ 
Tablo 3 incelediğinde yetenek yönetimi ile iş tatmini arasında orta düzeyde $(r=0,605, \mathrm{p}<0.001)$ ve anlamlı bir ilişki olduğu görülmektedir. Yetenek yönetimi boyutları ile iş tatmini arasındaki ilişkiye bakıldığında işletmeden ayrılma isteği boyutu dışında diğer boyutlarla iş tatmini arasında orta düzeyde ve anlamlı bir ilişki olduğu tespit edilmiştir. İşten ayrılma isteği ile iş tatmini arasında herhangi bir ilişki bulunmamaktadır $(r=0,033, p>0,05)$. Korelasyon analizi sonrasında değişkenler arasındaki etkiyi tespit edebilmek için regresyon analizi yapılmıştır. Yetenek yönetimi ve iş tatmini arasında bir ilişki olmadığı için bu boyut analize dahil edilmemiştir. Regresyon analizi sonuçları Tablo 4'te görülmektedir.

Tablo 4. Çoklu Regresyon Analizi Sonuçları

\begin{tabular}{|c|c|c|c|c|c|c|c|c|c|c|}
\hline \multicolumn{3}{|c|}{ Bağımlı Değişken } & \multicolumn{8}{|c|}{ Genel İş Tatmini } \\
\hline \multirow[t]{2}{*}{ Değişkenler } & \multicolumn{2}{|c|}{ Katsayilar } & \multicolumn{2}{|c|}{$\begin{array}{c}\text { Anlamlılık } \\
\text { Derecesi }\end{array}$} & \multirow{2}{*}{$\mathbf{R}^{2}$} & \multirow{2}{*}{$\begin{array}{c}\text { Düzeltilmiş } \\
\mathbf{R}^{2}\end{array}$} & \multirow[t]{2}{*}{ F } & \multirow[t]{2}{*}{$\mathbf{P}$} & \multirow[t]{2}{*}{ Tolerans } & \multirow[t]{2}{*}{ VIF } \\
\hline & B & Beta & $T$ & $P$ & & & & & & \\
\hline Sabit & 1,446 & & 14,123 & , 000 & \multirow{8}{*}{,402 } & \multirow{8}{*}{ 388 } & \multirow{8}{*}{29,339} & \multirow{8}{*}{,000 } & & \\
\hline $\begin{array}{l}\text { İşletmenin } \\
\text { sosyal } \\
\text { Sorumluluğu }\end{array}$ &,- 318 & , 595 & $-3,009$ & 003, & & & & & 039, & 25,715 \\
\hline $\begin{array}{l}\text { Yönetim } \\
\text { desteği }\end{array}$ &,- 438 & $\begin{array}{c}- \\
, 921\end{array}$ & $-4,008$ & , 000 & & & & & ,029 & 34,687 \\
\hline $\begin{array}{l}\text { İşletmede } \\
\text { sorumluluk } \\
\text { almaktan } \\
\text { duyulan } \\
\text { gurur }\end{array}$ &,- 337 & ,699 & $-3,110$ & , 002 & & & & & ,030 & 33,160 \\
\hline $\begin{array}{l}\text { Performans } \\
\text { yönetimi } \\
\text { uygulamaları }\end{array}$ &,- 231 & ${ }^{-}, 523$ & $-2,861$ & , 004 & & & & & 045, & 21,980 \\
\hline $\begin{array}{l}\text { Hijyen } \\
\text { faktörler }\end{array}$ &,- 267 & $\begin{array}{c}- \\
, 522\end{array}$ & $-3,198$ & , 001 & & & & & ,057 & 17,472 \\
\hline $\begin{array}{l}\text { İşletmeden } \\
\text { duyulan } \\
\text { memnuniyet }\end{array}$ &,- 264 & $\begin{array}{c}- \\
, 604\end{array}$ & $-3,117$ & , 002 & & & & & 041 & 24,674 \\
\hline $\begin{array}{l}\text { Kariyer } \\
\text { başarısı }\end{array}$ &,- 364 & $\begin{array}{c}- \\
, 793\end{array}$ & $-3,405$ & , 001 & & & & & ,028 & 35,651 \\
\hline $\begin{array}{l}\text { B = Standartla } \\
\text { ifade etmektec }\end{array}$ & aln & & yila & Bet & & thlaşt & $\mathrm{K}$ & & & \\
\hline
\end{tabular}

Tablo 4 incelendiğinde çoklu regresyon analizi sonuçları istatistiksel olarak anlamlıdır ( $F=29,339$, $\mathrm{p}<0,00)$. Düzeltilmiş $\mathrm{R}^{2}$ değeri $0,38^{\prime}$ dir. Bu sonuç, iş tatminindeki \% 38 oranındaki varyansın yetenek yönetimine ait boyutlar tarafından açıklandığını göstermektedir Tablodaki Beta katsayıları incelendiğinde sırasıyla yönetim desteği $(\beta=-438, p=, 000)$, kariyer başarısı $(\beta=-364$, $\mathrm{p}=, 001)$, işletmede sorumluluk almaktan duyulan gurur $(\beta=-337, p=, 002)$, işletmenin sosyal sorumluluğu $(\beta=-318, p=, 003)$, hijyen faktörler $(\beta=-267, p=, 001)$, işletmeden duyulan memnuniyet $(\beta=-264, p=, 002)$, işletmeden ayrılma isteği $(\beta=-235, p=, 004)$, performans yönetimi uygulamaları $(\beta=-231, \mathrm{p}=, 004)$ iş tatminini üzerinde etkili olduğu görülmektedir. 


\section{SONUÇ}

Turizm sektöründe çalışanların kendilerini mutlu hissetmeleri bunun yanında olumsuz tutumlar sergilememeleri, işletmelerin insan kaynakları uygulamalarını doğru ve amacına uygun yönetebilmesi oldukça önemli olmaktadır. Otel işletmelerinde işgörenlerin sahip olduğu yetenekler önemli bir kalite göstergesi olmaktadır. Yetenekler aynı zamanda iş ile ilgili gerekler ve işin en iyi şekilde yapılması ile ilgili işgören niteliklerini de göstermektedir. Otel işletmeleri 24 saat hizmet veren ve emek yoğun işletmelerdir. Bu nedenle insan kaynağı verilen hizmetin niteliği ve standardı açısından oldukça önemli olmaktadır. Dolayısı ile bu işletmelerde yetenekler işe alma, terfi, işten çıkarma, vb. işgören hareketlerinde önemli bir dayanak olmaktadır (Akoğlan Kozak ve Özdemir, 2013).

Bu çalışmada, turizm işletmelerinde çalışanların yetenek yönetiminin iş tatmini üzerindeki etkisi ortaya konmuştur. Araştırma sonuçlarına göre yetenek yönetimi alt boyutları (yönetim desteği, işletmenin sosyal sorumluluğu, işletmede sorumluluk almaktan duyulan gurur, performans yönetimi uygulamaları, hijyen faktörleri, işletmeden duyulan memnuniyet, kariyer başarısı ve işletmeden ayrılma isteği) ile iş tatmini arasında istatistiksel olarak anlamlı bir ilişki olduğu sonucuna varılmıştır. Bu sonuç literatürde yer alan diğer çalışmaların (Serim Bahadınlı, 2013; Hamidi, Saberi ve Safari, 2014; Tash, Ali ve Ahmadzadeh, 2016; Kamal ve Lukman, 2017; Hafez vd., 2017; Yalçın, 2017; İpçioğlu, 2017; Tarakcı ve Öneren, 2018; Lei, Basit ve Hassan, 2018; Dixit ve Arrawatia, 2018; Altındağ, Çırak ve Acar, 2018; Akgemci, Canbolat ve Kalfaoğlu, 2020) sonuçlarını desteklemektedir. Bu sonuçlardan hareketle konaklama işletmelerinin yetenekli çalışanları işletmede tutabilmeleri ve iş tatminlerinin yüksek olmasını sağlamaları için işin yapısına uygun ücretin verilmesi, iş güvencesinin sağlanması, olumlu bir örgüt kültürü oluşturması, performansa dayalı ödüller vermesi, çalışanların kariyer gelişimi ve yükselme fırsatlarını destekleyen politikalar benimsemesi ve çalışanlara işlerini daha iyi yapmalarına imkân tanıyacak uygun eğitimleri vermesi (Türk ve Akbaba, 2017) çalışanların iş tatminleri üzerinde olumlu etki yaratacağı söylenebilir. Böylelikle işletmeye alınan yetenekli çalışanlar işletmede uzun süre istihdam edilebilecektir

Yetenek yönetimi alt boyutlarından "işletmenin sosyal sorumluluğu, yönetim desteği, işletmede sorumluluk almaktan duyulan gurur, performans yönetimi, hijyen faktörleri, işletmeden duyulan memnuniyet, kişisel başarı" ile "iş tatmini" arasında anlamlı pozitif bir etki ortaya çıkmıştır. Ancak "işletmeden ayrılma isteği" alt boyutu ile "iş tatmini" arasında herhangi bir ilişki tespit edilmemiştir. İşten ayrılma isteği ifadelerinin işgörenlerin tarafından olumsuz olarak algılanması veya yönetim tarafından denetlenme korkusu yüzünden sorularını cevaplamada çekimser kalmaları nedeniyle cevaplamaktan kaçınmaları olabilir. Araştırma sonuçları işgörenlerin düşük iş tatmin düzeylerini ortadan kaldırmak için yetenek yönetimi uygulamalarına önem verilmesi gerektiğini göstermektedir. Çünkü otel işletmelerinde etkin bir yetenek yönetim sisteminin olması işgörenlerin kendilerine önem verdiklerini hissetmelerine ve iş tatminlerini arttırarak işletmeye olan bağlllıkları üzerinde etkili olacaktır (Duran ve Sevinç, 2018). İşgörenlerin iş tatminlerinin düşük olması beraberinde işgücü devir hızını yükselteceği ve çalışanların örgüte bağlılık hissedemedikleri için işten ayrılma niyetlerini artıracağı söylenebilir.

Turizm sektöründe üretim ve tüketimin eşzamanlı yapılması ve emek yoğun bir sektör olması (İçöz ve Kozak, 1998) nedeniyle işletme için önemli bir unsur olan insan kaynağı rakiplere karşı önemli bir avantaj yaratmaktadır (Kuşluvan, Kuşluvan, İlhan ve Buyruk, 2010; Çetintürk, 2017) $\mathrm{Bu}$ nedenle işgörenleri işletmede tutan ve rekabet avantajı sağlamak isteyen turizm işletmeleri için iş tatmini her geçen gün gerekli hale gelmektedir. Başarılı olmak isteyen otel işletmeleri yetenek yönetimi ile ilgili stratejilerini oluşturarak, yetenekli işgörenlerine kendilerini gelişme imkânı tanımalı, kariyer gelişimlerine katkı sağlamak için eğitim vermeli yedekleme ve 
ödüllendirmelidir (Duran ve Sevinç, 2018). Yetenek yönetimini başarı ile uygulayan dünyaca ünlü zincir otel olan Ritz Carlton Otel yöneticileri yetenek yönetiminin zorlu bir süreç olduğunu belirtmektedir. Yetenek yönetimi konusunda başarılı olan bu işletmede işgören alımı ile bu süreç başlamaktadır. İşletmeye uygun yetenekler belirlendikten sonra kendi hizmet standartlarına uygun olarak hazırladıkları altın kurallar çalışanlara aktarılmakta, onlara bu eğitimi verecek işletme içinden bir koç/mentor atanmakta ve ilk yirmi bir gün bu eğitim verildikten sonra işgörenlere sertifika verilmektedir. Ritz Carlton Otel Asya Pasifik Bölge Yardımcısı otel tarafından uygulanan eğitim ve beceri sertifikasyon sisteminin işletmelere uluslararası pazarlarda rekabet avantajı kazandırdığını belirtiyor. Ritz Carlton'a katılan işgörenler ilk yılda 250 saat eğitim alıyorlar ve sürekli bir koç/mentorla beraber çalışma fırsatı buluyorlar (Michelli, 2019). Ayrıca kariyer rotaları oluşturularak markanın farklı işletmelerinde çalışma ve daha sonrasından koçluk/mentorluk yapma imkanı bulmaktadır. Bu durum işgörenlerin iş tatmini üzerinde de olumlu etki yaratmaktadır.

Sonuç olarak turizm işletmeleri için rakipler tarafından kopyalanamayacak ve taklit edilemeyecek en önemli kaynak insan kaynağı olmaktadır. Dolayısıyla yetenekli işgörenleri işletmede tutmak isteyen konaklama işletmeleri doğru işgücü stratejisini belirlemeli, doğru yeteneği işe almalı ve geliştirmeli, işgörenlere liderlik etmeli, işletmede çalışan işgörenleri lider olarak yetiştirmeli ve aynı zamanda günümüz gerekliliği olan dijital çağa ayak uydurabilmek için işgörenleri eğitmelidir. Başarılı bir yetenek yönetim sistemi uygulayan otel işletmeleri sürdürülebilir rekabet üstünlüğü ve üstün performans elde edebilecektir. Yetenek yönetiminin önemini vurgulamak için Bill Gates, "çalışanlarımızdan en iyi yirmi insan olmadığında Microsoft'un önemsiz bir işletme haline geleceğini söyleyebilirim" demiştir. Otel işletmeleri için de yetenekli çalışanlar aynı derecede öneme sahip olmaktadır.

\section{KAYNAKÇA}

Abdolshah, M., Khatibi, S. A. M. and Moghimi, M. (2018). Factors Influencing Job Satisfaction of Banking Sector Employees (The case study: Asgariyeh and Mehr Iran Banks in Qazvin and Alborz, Iran), Journal of Central Banking Theory and Practice, (1): 207-222.

Ağraş, S. ve Kılınç, İ. (2014). Örgütsel Yeteneklerin Türkiye'deki Otel İşletmeleri Bağlamında Analizi, Manas Sosyal Araştırmalar Dergisi, 3(4): 1-35.

Ahmed, H. K. (2016). The Impact of Talent Management on the Competitive Advantage in the Organizations, Proceedings of 37th ISERD International Conference, Abu Dhabi, UAE, p.28-36.

Ak, M. (2017). Örgütsel Bağlllı̆̆ın Örgütsel Etkililik Üzerinde Etkisi: Bir Değerlendirme, Anadolu Kültürel Araştırmalar Dergisi, 1(3): 27-42.

Akar, F. (2015). Yetenek Yönetimi. İstanbul: İmge Kitabevi Yayınları.

Akar, F. ve Balcı, A. (2016). Yetenek Yönetiminin Bazı Türk Üniversitelerinde Uygulanmasına İlişkin Öğretim Üyesi Görüşleri, Kastamonu Ĕ̆itim Dergisi, 24(2): 955-974.

Akgöz, E. (2016). Turizm İşletmelerinde İnsan Kaynakları Yönetimi, (Editör) Akgöz, E: Turizm Paradigmaları içinde, Ankara: Detay Yayıncılık.

Akıncı, Z., ve Yüzbaşıŏlu, N. (2015). Türkiye, Dünya Turizm Sektörü İçerisinde Bir Belirleyici mi, Yoksa Bir Taşıyıcı mı?. Finans Politik ve Ekonomik Yorumlar, (609), 45-61.

Akinbobola, O. I. (2011). Conflict in Human Capital Relationships: The Impact of Job Satisfaction on Job Involvement in a Workplace, International Journal of Social Science and Humanity, 1(2): 9295. 
Aksoy, M. ve Sökmen, A. (2018). Algılanan Örgütsel Desteğin Örgütsel Çıktılar Üzerine Etkileri Otel İşletmelerinde Bir Araştırma, Journal of Tourism and Gastronomy Studies, 6(1): 200-212.

Aksu, N. (2012). İş Tatmininin Bazı Demografik Değişkenler Açısından İncelenmesi, Polis Bilimleri Dergisi, 14(1): 59-79.

Albeni, M. ve Ongun, U. (2005). Antalya Turizminin Türk Turizminin İçerisindeki Yeri ve Krizlerin Antalya Turizmi Üzerindeki Etkisi, Süleyman Demirel Üniversitesi, İktisadi ve İdari Bilimler Fakültesi Dergisi, 10(2): 93-112.

Alpaslan, C. ve Tutar, F. (2013). Medeniyetlerin Yaşatıldığ 1 Şehir Niğde ve Turizm, Organizasyon ve Yönetim Bilimleri Dergisi, 5(1): 47-61.

Altıntaş, M. (2018). İnsan Kaynaklarında Yeni Bir Yaklaşım: Yetenek Yönetimine İlişkin Nitel Bir Araştırma, Kırşehir Ahi Evran Üniversitesi İktisadi ve İdari Bilimler Fakültesi Dergisi (AEUï̈BFD), 2(1): $24-43$.

Altunoğlu, A. E., Atay, H. ve Terlemez, B. (2015). İnsan Kaynakları Bakış Açısından Yetenek Yönetimi: Bankacılık Sektörü Uygulama Örneği, Marmara Üniversitesi, İ.İ.B. Dergisi, 37(1): 47-70.

Amalia, L. (2018). The Influence of Job Involvement and Job Satisfaction toward Employee Turnover Intention (Case in Indonesia Broadcasting), IOSR Journal of Business and Management, 20(5): 11-18.

Annakis, J., Dass, M. and Isa, A. (2014). Exploring Factors that Influence Talent Management Competency of Academics in Malaysian GLC's and Non- Government Universities, Journal of International Business and Economics, 2(4): 163-185.

Arslan, M. L. (2012). İnsan Kaynakları Gereksinime Süreç Yaklaşımı: Stratejik İnsan Kaynakları Planlaması, Öneri, 10(37): 89-101.

Aypar, S., Sökmen, A. ve Ekmekçioğlu, E. B. (2018). İş Tatmini ve İşten Ayrılma Niyeti İlişkisi Örgütsel Özdeşleşmenin Aracılık Rolü, Gazi Üniversitesi Sosyal Bilimler Dergisi, 5(13): 116-124.

Aytaç, T. (2014). Okullarda Bütünleştirilmiş Yetenek Yönetimi Modeli: Öğretmen Görüşleri, Eğitim Bilimleri Dergisi, (39): 1-24.

Aziri, B. (2011). Job Satisfaction, A Literature Review, Management Research and Practice, 3(4): 7786.

Bağcı, Z. ve Demir, G. (2017). Örgütlerde Adalet Algısının İş Tatmini Üzerine Etkisi: Akdeniz Üniversitesi İdari Personeli Üzerinde Bir Araştırma, Manas Sosyal Araştırmalar Dergisi, 6(4): 343357.

Bahadanlı, H. S. (2013). İşletmelerde Yetenek Yönetimi Uygulamalarının Çalışanların İş Tatmini ve Örgüte Bağlılıkları Üzerindeki Etkisi (İlaç, Tekstil ve Otomotiv Sektörlerinde Araştırma), Yayımlanmamış Doktora Tezi, Marmara Üniversitesi, İstanbul.

Baqutayan, S. M. S. (2014). Is Talent Management Important? An Overview of Talent Management and the Way to Optimize Employee Performance, Mediterranean Journal of Social Sciences, 5(23): 2290-2295.

Başbuğa, B., Karagün, K. ve Ekiz, Z. D. (2018). Antrenör ve Sportif Eğitim Uzmanlarının Örgütsel Stres ile İş Doyum Düzeyleri, Eğitim ve Öğretim Araştırmaları Dergisi, 7(3): 17-26.

Başcıllar, M. ve Taşci, A. (2018). İş Yükü ve İş Tatmini Arasındaki İlişki: Sosyal Hizmet Uzmanları Üzerine Bir Araştırma, IGUSABDER, (4): 330-344. 
Bat, M. and Yalçın, M. (2015). An Evaluation of Talent Management from an Organizational Perspective: The Case of Vodafone, Global Media Journal TR Edition, 6(11): 90-111.

Benligiray, S. (2004). İnsan Kaynakları Yönetimi, (Editör) Geylan, R: İnsan Kaynakları Örgütlemesi ve Yönetimi içinde (1-28), Eskişehir: Anadolu Üniversitesi.

Bozkurt, Ö. ve Bozkurt, İ. (2008). İş Tatminini Etkileyen İşletme İçi Faktörlerin Eğitim Sektörü Açısından Değerlendirilmesine Yönelik Bir Alan Araştırması, Doğuş Üniversitesi Dergisi, 9(1): 118.

Can, Y., Soyer, F. ve Bayansalduz, M. (2009). Sporcuların İş Tatmini ile Lider Bağlıllğı ve Örgütsel Bağlılık Duyguları Arasındaki İlişkilerin İncelenmesi, Niğde Üniversitesi Beden Eğitimi ve Spor Bilimleri Dergisi, 3(3): 228-238.

Collings, D. G. and Mellahi, K. (2009). Strategic Talent Management: A Review and Research Agenda, Human Resource Management Review, 19(4): 304-313.

Çekmecelioğlu, H. (2006). İş Tatmini ve Örgütsel Bağlllık Tutumlarının İşten Ayrılma Niyeti ve Verimlilik Üzerindeki Etkilerinin Değerlendirilmesi: Bir Araştırma, İş, Güç Endüstri İlişkileri ve Insan Kaynakları Dergisi, 8(2): 153-168.

Çetïntürk, İ. (2017). Turizm İşlemelerinde Sürdürülebilir Rekabet Üstünlüğü Kaynağı Olarak Stratejik İnsan Kaynakları Yönetimi, Journal of Yaşar University, 12(45): 60-75.

Çetintürk, İ. (2017). Turizm İşlemelerinde Sürdürülebilir Rekabet Üstünlüğü Kaynağı Olarak Stratejik İnsan Kaynakları Yönetimi, Journal of Yaşar University, 12(45): 60-75.

Çevik, B. (2014). Turizm Sektöründe Yetenek Yönetimi Uygulamaları: Antalya Yöresinde Beş Yıldızlı Otellerde Bir Araştırma, Yayınlanmamış Yüksek Lisans Tezi, Akdeniz Üniversitesi, Antalya.

Demir, H., Usta, R. ve Okan, T. (2008). İçsel Pazarlamanın Örgütsel Bağlllık ve İş Tatminine Etkisi, H.Ü. İktisadi ve İdari Bilimler Fakültesi Dergisi, 26(2): 135-161.

Demirdelen, D. ve Ulama, Ş. (2013). Demografik Değişkenlerin Kariyer Tatminine Etkileri: Antalya'da 5 Yıldızlı Otel İşletmelerinde Bir Araştırma, İşletme Bilimi Dergisi, 1(2): 65-89.

Duran, E. ve Sevinç, F. (2018). Turizm İşletmelerinde Yetenek Yönetim Sistemi ve Gereklilikleri, (Editör) Eşitti, B: Turizm İşletmelerinde Yetenek Yönetimi içinde Çanakkale: Paradigma Akademi.

Erdil, O., Keskin, H., İmamoğlu, Z. S. ve Erat, S. (2004). Yönetim Tarzı ve Çalışma Koşulları, Arkadaşlık Ortamı ve Takdir Edilme Duygusu ile İş Tatmini Arasındaki İlişkiler: Tekstil Sektöründe Bir Uygulama, Doğuş Üniversitesi Dergisi, 5(1): 17-26.

Ergin, C. (1997). Bir İş Doyumu Ölçümü Olarak İş Betimlemesi Ölçeği: Uyarlama, Geçerlik ve Güvenirlik Çalışması, Türk Psikoloji Dergisi, 12(39): 25-36.

Eroğlu, E. (2002). Örgütsel İletişim Kalitesi İçin Toplam Motivasyon Yönetimi, Kurgu Dergisi, (19): $163-168$

Erol, N. (2010). Küreselleşme Sürecinde Örgütleri Yeniden Düşünmek, Akademik Bakış, 4(7): 7989.

Fidan, M. ve Küçükali, R. (2014). İlköğretim Kurumlarında Yöneticilerin İletişim Becerileri ve Örgütsel Değerler, Ĕ̆itim Bilimleri Araştırmaları Dergisi, 4(1): 317-334.

Gül, H., Oktay, E. ve Gökçe, H. (2008). İş Tatmini, Stres, Örgütsel Bağlllık, İşten Ayrılma Niyeti ve Performans Arasındaki İlişkiler: Sağlık Sektöründe Bir Uygulama, Akademik Bakış, (15): 1-11. 
Gürbüz, A. ve Uçar, M. (2017). Turizm Destinasyonu Kimliği ile Yaşam Kalitesi Arasındaki İlişki: Safranbolu'daki Turizm Sektörü Çalışanları Üzerine Bir Araştırma, Akademik Sosyal Araştırmalar Dergisi, (61): 539-552.

Gürbüz, S., ve Şahin, F. (2014). Sosyal bilimlerde araştırma yöntemleri. Ankara: Seçkin Yayıncılık.

Hafez, E., Abouel Neel, R. and Elsaid, E. (2017). An Exploratory Study on How Talent Management Affects Employee Retention and Job Satisfaction for Personnel Administration in Ain Shams University Egypt, Journal of Management and Strategy, 8(4): 1-17.

Islam, J. N., Mohajan, H. K. and Datta, R. (2012). A Study on Job Satisfaction and Morale of Commercial Banks in Bangladesh, International Journal of Economics and Research, 76-96.

Karakaya, A. ve Uçar, M. (2015). İş Esnekliğinin İşgören Motivasyonuna Etkisi, Karabük Üniversitesi Sosyal Bilimler Enstitüsü Dergisi, (Özel Sayı I): 19-35.

Karataş, S. ve Güleş, H. (2010). İlköğretim Okulu Öğretmenlerinin İş Tatmini ile Örgütsel Bağl1llğ 1 Arasındaki İlişki, Uşak Üniversitesi Sosyal Bilimler Dergisi, 3(2): 74-89.

Kasraei, A., Dadkhah, M. and Mirabbasi, S. M. (2013). Assessing Prioritizing the Key Factors Affecting Job Involvement of the Employees Among Holding Company of Production, Transmission and Distribution of Electricity Management (Tavanir), European Online Journal of Natural and Social Sciences, 2(3): 314-319.

Katlav, E. Ö. ve Perçin, N. Ş. (2019). Algılanan Etkileme Taktiklerinin İş Performansı Üzerindeki Etkisini Belirlemede Kontrol Odağının Düzenleyici Rolü: Otel İşletmelerinde Bir Uygulama, Sosyal Bilimler Araştırmaları Dergisi, 225-244.

Kaur, R. (2013). Empirical Study of Talent Management Program and Its Impact on the Employee's Retainment and Performance in Indian Supermarket Big Bazaar, Human Resource Management Research, 3(3): 61-70.

King, K. A. (2015). Global Talent Management: İntroducing A Strategic Framework and Multipleactors Model, Journal of Global Mobility: The Home of Expatriate Management Research, 3(3): 273-288.

Kitapçı, H. ve Sezen, B. (2002). Çalışanların Tatminini Belirleyici Unsurlar Üzerine Bir Araştırma: Kariyer Süreci Örneği, Fırat Üniversitesi Sosyal Bilimler Dergisi, 12(1): 219-230.

Kozak, M. ve Özdemir, C. (2013). Yetenek Kavramının Otel İşletmelerinde Operasyonel Personel Bağlamında Değerlendirilmesi, Seyahat ve Otel İşletmeciliği Dergisi, 10(1): 6-19.

Kök, B. S. (2006). İş Tatmini ve Örgütsel Bağlllı̆̆ın İncelenmesine Yönelik Bir Araştırma, İktisadi ve İdari Bilimler Dergisi, 20(1): 291-317.

Kuşluvan, S., Kuşluvan, Z., İlhan, I. and Buyruk, L. (2010). The Human Dimension a Review of Human Resources Management Issues in the Tourism and Hospitality Industry, Cornell Hospitality Quarterly, 51(2): 171-214.

lyria, K. R. (2013). Role of Talent Management on Organization Performance in Companies Listed in Naibobi Security Exchange in Kenya: Literature Review, International Journal of Humanities and Social Science, 3(21): 285-290.

Manpower Türkiye, Yetenek Açığı Raporu, (2019). Erişim Linki: https://www.manpower.com.tr/arastirmalar/2019-yetenek-acigi-arastirmasi, Erişim Tarihi: 10.03.2021. 
Michelle, J. A. (2019). Training the Talented, the Ritz-Carlton Way. [Online] https://www.amanet.org/articles/training-the-talented-the-ritz-carlton-way/ [Erişim Tarihi: 05.04.2021].

Özkoç, A. G. and Çalışkan, N. (2015). The Impact of Organizational Envy on Organizational Climate Created among Employees: An Application in Accommodation Enterprises, International Journal of Business and Management, 10(1): 40-49.

Özkoç, A. G. ve Katlav, E. Ö. (2015). Konaklama İşletmelerinde Örgüt Kültürünü Etkileyen Ulusal Kültür Boyutlarının Belirlenmesi, Çukurova Üniversitesi Sosyal Bilimler Enstitüsü Dergisi, 24(1): 115130.

Öztürk, Y. ve Alkış, H. (2011). Konaklama İşletmelerinde Çalışanların İş Tatmininin Ölçülmesi Üzerine Bir Araştırma, ZKÜ Sosyal Bilimler Dergisi, 7(14): 437-460.

Poyraz, K. ve Kama, B. (2008). Algılanan İş Güvencesinin, İş Tatmini, Örgütsel Bağlllık ve İşten Ayrılma Niyeti Üzerindeki Etkilerinin İncelenmesi, Süleyman Demirel Üniversitesi İktisadi ve İdari Bilimler Fakültesi Dergisi, 13(2): 143-164.

Ratih, D. and Yunus, A. (2016). Labor Union and The Company Performance: Industrial Conflict, International Journal of Business, Economics and Law, 11(1): 1-10.

Serim Bahadınlı, H., (2013). İşletmelerde Yetenek Yönetimi Uygulamalarının Çalışanların İş Tatmini ve Örgüte Bağlllıklar Üzerindeki Etkisi (İlaç, Tekstil ve Otomotiv Sektörlerinde Araştırma), Yayınlanmamış Yüksek Lisans Tezi, Marmara Üniversitesi, İstanbul.

Shiel, G. and Cartwright. F. (2015). Analyzing Data from A National Assessment of Educational Achievement. Washington DC: World Bank Group.

Spector, P. E. (1997). Job Satisfaction: Application, Assessment, Causes, and Consequences, Thousand Oaks Cliff: Sage Publications, Inc.

Şahin, S. (2013). Gençlik Hizmetleri ve Spor İl Müdürlerinin İş Doyumu ve Örgütsel Bağlllıkları Arasındaki İlişkinin İncelenmesi, NWSA-Sports Sciences, 8(1): 12-25.

Turkish-English Dictionary, (2020). www.tureng.com, [Erişim Tarihi: 08.10.2020].

Tutar, H., Altınöz, M. ve Çöp, S. (2011). İşletmelerde Yetenekli Çalışanların Örgütsel Bağlılıklarının Artırılmasına Yönelik Bir Araştırma, Çanakkale Onsekiz Mart Üniversitesi, 19. Ulusal Yönetim ve Organizasyon Kongresi, 306-312.

Tuna, M. (2007). Personel devir oranı analizi: Ankara'da yer alan yıldızlı otel işletmelerinde bir uygulama. Anatolia: Turizm Araştırmaları Dergisi, 18(1), 45-52.

Türk Dil Kurumu Sözlüğü, (2020) www.tdk.gov.tr, [Erişim Tarihi: 08.10.2020].

Türk, M., ve Akbaba, M. (2017). Turizm işletmelerinde yetenek yönetimi algılamalarının örgütsel uyum ve işten ayrılma niyeti üzerine etkisi, The Journal of Academic Social Science Studies, 62: 465479.

Üngüren, E., Doğan, H., Özmen, M. ve Tekin, A. Ö. (2010). Otel Çalışanlarının Tükenmişlik ve İş Tatmin Düzeyleri İlişkisi, Journal of Yasar University, 17(5): 2922-2937.

Vnoučkova, L. (2016). Practices of Talent Management in Organisations in the Czech Republic, Acta Universitatis Agriculturae et Silviculturae Mendelianae Brunensis, 64(2): 701-709.

Waheed, S. and Zaim, A. H. (2015). A Model for Talent Management and Career Planning, Educational Sciences: Theory \& Practice, 15(5): 1205-1213. 
Yaya, J. A. (2016). The Effect of Human Capital Development on Job Satisfaction of Librarians in Public Universities in Nigeria, American Journal of Business and Society, 1(3): 98-117.

Yeşilyurt, H. ve Koçak, N. (2014). İş Doyumu ve Örgütsel Vatandaşlık Davranışı Arasındaki İlişkinin Otel İşletmeleri Açısından İncelenmesi, Dokuz Eylül Üniversitesi Sosyal Bilimler Enstitüsü Dergisi, 16(2): 303-324.

Yüksel, İ. (2005). İletişimin İş Tatmini Üzerindeki Etkileri: Bir İşletmede Yapılan Görgül Çalışma, Doğuş Üniversitesi Dergisi, 6(2): 606. 